Gap felling as a forest harvesting method in boreal forests : responses of carabid beetles (Coleoptera, Carabidae)

Koivula, M.

Blackwell

2003

Koivula, M. and Niemelä, J. 2003. Gap felling as a forest harvesting method in boreal pÿforests: responses of carabid beetles (Coleoptera, Carabidae). Ecography 26: 179187.

http://hdl.handle.net/1975/282

Downloaded from Helda, University of Helsinki institutional repository.

This is an electronic reprint of the original article.

This reprint may differ from the original in pagination and typographic detail.

Please cite the original version. 


\title{
Gap felling as a forest harvesting method in boreal forests: responses of carabid beetles (Coleoptera, Carabidae)
}

\author{
Matti Koivula and Jari Niemelä
}

\begin{abstract}
Koivula, M. and Niemelä, J. 2003. Gap felling as a forest harvesting method in boreal forests: responses of carabid beetles (Coleoptera, Carabidae). - Ecography 26:
\end{abstract} $179-187$.

\begin{abstract}
In order to study the ecological effects of logging combined with mechanical soil preparation, we sampled carabid beetles with pitfall trapping in nine spruce-dominated stands in central Finland in 1995-1998. Three of the stands were left intact as controls. Three $1600-\mathrm{m}^{2}$ openings per stand were logged in the winter 1995-1996 into six stands. In three of these stands, light soil preparation was applied. Logging affected the species assemblages, but soil preparation per se had no clear effects. Open-habitat species increased in abundance in the openings one year after logging, but catches of generalist species in the different treatments did not differ from each other. A forest species, Calathus micropterus, was least abundant in the prepared openings. The amounts of logging residue, exposed mineral soil and aggregated humus, as well as the abundance of red wood ants, significantly explained variation in carabid assemblages.
\end{abstract}

M. Koivula (matti.koivula@helsinki.fi) and J. Niemelä, Dept of Ecology and Systematics, Div. of Population Biology, P. O. Box 65, FIN-00014, Univ. of Helsinki, Finland.

Large-scale logging isolates mature and old-growth forests and increases the amount of edge habitat (Andrén 1997, Angelstam 1997, Esseen et al. 1997). Consequently, the structure of boreal plant and animal assemblages, the heterogeneity of landscape structure and continuity of mature stands have changed (Niemelä 1997, 1999, Esseen et al. 1997). In Finland, for example, over $30 \%$ of the red-listed species are threatened by forestry (Rassi et al. 2000). In order to prevent further losses of species, management should maximise landscape-scale habitat diversity and guarantee the availability of old-growth forests (Niemelä et al. 1993a, b). Protecting as much remaining old-growth forests as possible is imperative for the protection of old-growth forest specialists, but also the restoration of mature managed stands is essential (Mönkkönen 1999, Niemelä 1999, Heikkinen et al. 2000).

In addition to protecting old-growth, forest harvesting practices must change, if forest biodiversity is to be maintained in Fennoscandia. Forest management should emulate natural processes, blend natural structures and include natural composition into the stands (Haila et al. 1994, Fries et al. 1997). Steps towards ecological sustainability have been taken in Finnish and Swedish forest management guidelines and forestry laws (Hallman et al. 1996, Savolainen 1997, Angelstam and Pettersson 1997). For example, decaying wood is often left behind in the logged stands and the sizes of clear-cuts have decreased to 3-4 ha. Moreover, ploughing, which is applied to help tree saplings to establish in the clear-cuts, is often replaced in Fennoscandia by lighter mechanical soil preparation, which removes the humus layer in narrow strips (width ca $50 \mathrm{~cm}$ ), and is also a subject of this study.

Movement patterns of carabid beetles (Coleoptera, Carabidae) in ploughed stands have been studied in Poland (Sklodowski 1999), but differences among assemblages of differently treated sites were not analysed. Szyszko (1990) showed in Polish pine forests that there was a negative relationship between the severity of soil

Accepted 14 June 2002

Copyright (C) ECOGRAPHY 2003

ISSN 0906-7590

ECOGRAPHY 26:2 (2003) 
alteration and the recovery of forest-carabid assemblages. Furthermore, Desender et al. (1999) showed that, with large-scale logging and heavy alteration of the soil, recovery of the forest-carabid fauna may take hundreds of years. Thus, we hypothesized that changes in carabid-beetle assemblages should be less pronounced in clear-cuts without soil preparation, compared to those of clear-cuts with soil preparation. In this paper, we focus on how relatively slight alteration of the soil surface in small clear-cuts affects carabid beetles.

\section{Material and methods}

\section{The study areas and sampling design}

The study was conducted in central Finland, in the southern boreal zone (Ahti et al. 1968), in three separate areas located in the municipalities of Kuorevesi, Längelmäki and Orivesi, within an ca $50 \times 50 \mathrm{~km}$ area (Fig. 1). The study forests consisted of spruce (Picea abies (L.) Karsten) dominated Myrtillus-type stands (Cajander 1949). The age of the dominant trees was $80-120 \mathrm{yr}$, the stands were previously managed but no thinning or other management activities had been applied for at least $10 \mathrm{yr}$ before the experiment. Before logging, the understory vegetation was dominated by Vaccinium vitis-idaea and $V$. myrtillus dwarf shrubs, and Dicranum, Pleurozium and Hylocomium mosses. The surroundings of the study stands varied from recently logged stands to mature $(90-150$ yr) spruce forests.

There were three stands, within a $3-\mathrm{km}$ radius, in each study area (Fig. 1) giving a total of nine stands. Each stand consisted of a one-hectare treatment square and its immediate surroundings. The distance between adjacent stands within a study area varied between 50 and $1500 \mathrm{~m}$, the stands being separated by a road or a different stand type (dissimilar in forest type, age and species distribution of dominant trees). The stands within each area were thus independent of each other for carabids (Digweed et al. 1995), and were randomly assigned to a treatment in spring 1995, prior to the commencement of the experiment.

Of the three stands in each study area, two stands were subjected to gap felling by cutting three $40 \times 40 \mathrm{~m}$ or $32 \times 50 \mathrm{~m}$ clear-cut openings in each (ca $40-50 \%$ of the trees were removed; hereafter referred to as gapfelled stands). The minimum distance between openings was $15 \mathrm{~m}$ (Fig. 1). One of the three stands in each area was left as an uncut control, and the openings of one of the two logged stands in each area were subjected to mechanical soil preparation.

The study design follows the Before/After with Control/Impact design (BACI, Underwood 1991). Data were collected both before and after logging, and in the control (not logged) and impacted (two treatments) stands. The study began in 1995 (pre-treatment study year), and the stands were logged the following winter (1995-1996) by the land-owning forestry companies. Mechanical soil preparation was applied in the summer of 1996, and the post-treatment sampling was carried out during three years (1996-1998).

The beetles were collected using pitfall traps. To ensure that the locations of the traps would be exactly the same before and after logging, we used 20-cm-long steel nails with a coloured plastic band to mark the trapping sites. In each stand, the traps were placed in six groups, each group with four pitfalls arranged in a $4 \times 4 \mathrm{~m}$ square $(24$ traps $/$ stand $\times 3$ stands $\times 3$ areas $=$ 216 traps). Within a stand, trap groups were placed at least $25 \mathrm{~m}$ from each other, and at least $30 \mathrm{~m}$ from the nearest forest edge. Thus, trap groups were independent from each other (Digweed et al. 1995). In the stands subjected to logging, three trap groups were placed in

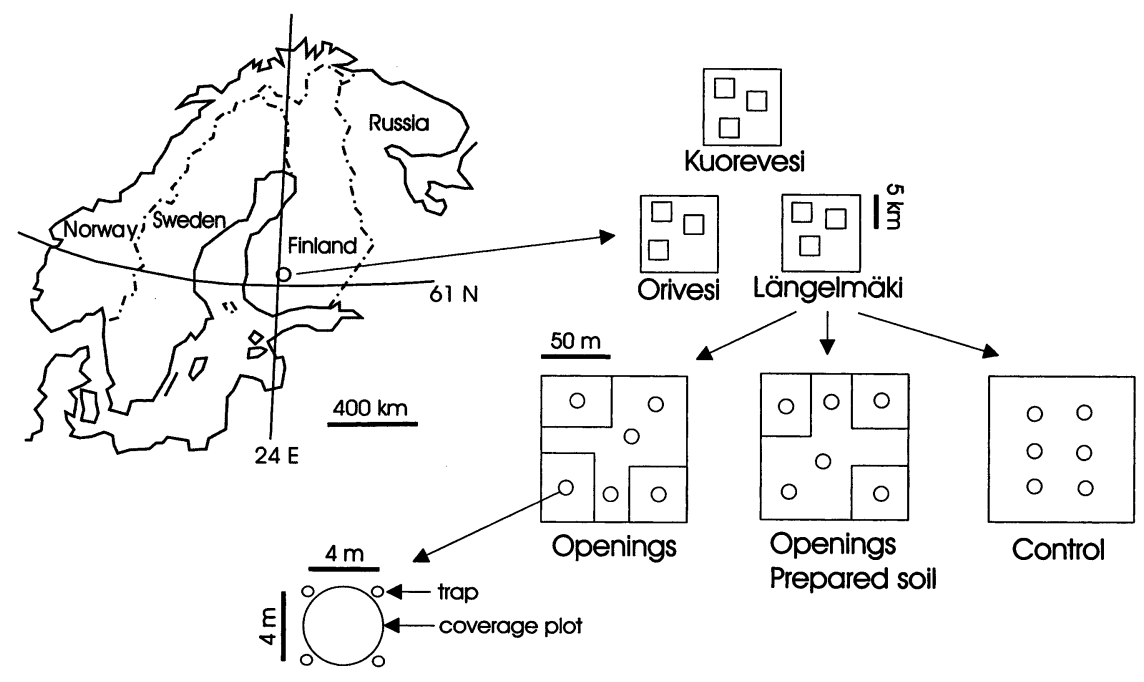

Fig. 1. The locations of the study sites and the study design. Within each of the three study areas, there were three stands representing the different treaments. There were six groups of four pitfall traps in each stand. Within each stand with openings, there were three small clear-cuts, and three trap groups were in the centers of the openings, and three were in the unlogged sites. 
the clear-cut areas, and three in the unharvested areas (Fig. 1).

The traps (depth $68 \mathrm{~mm}$ and mouth diameter $66 \mathrm{~mm}$ ) were partly filled with $30 \%$ propylene glycol and detergent, and were covered with $10 \times 10 \mathrm{~cm}$ plexi roofs to protect them from litter and rain. The trapping covered the whole growing season (from mid-May to early September) each year, and the traps were emptied once a month. The carabids were identified by MK. The nomenclature follows Lindroth (1985, 1986). Having been shown previously to correlate negatively with the abundance of carabids (e.g. Koivula et al. 1999), catches of red wood ants were used to analyse their effects on beetle catches.

The percent coverage of the ground by visible mineral soil, drifted humus and logging residue, was estimated annually in plots of a 2-m radius centred within the boundaries of each trap group (Fig. 1).

\section{Data analyses}

The beetle data were standardised to individuals caught per 100 trapping days, and then $\log (\mathrm{X}+1)$ transformed, to improve the normalities of the distributions. The data were analysed with repeated measures analysis of variance (ANOVA). In order to standardise the samples (according to their pre-treatment catches), we calculated relative after-treatment catches for the years 1996-1998 (for $1996=\mathrm{catch}_{1996} / \mathrm{catch}_{1995}$, for $1997=$ catch $_{1997} / \mathrm{catch}_{1995}$, and for $\left.1998=\mathrm{catch}_{1998} / \mathrm{catch}_{1995}\right)$. In each control stand, three out of six within-stand, randomly chosen sites represented imaginarily "logged' sites, and three of the sites represented "unlogged" sites. In the ANOVA model, the three areas were treated as blocks. Each area had six treatment factors (see Fig. 1), each of them with three replicates (= groups of four traps): 1) "unlogged" control, 2) "logged" control, 3) unlogged and 4) logged sites within gap-felled stands with unprepared openings, and 5) unlogged and 6) logged sites within gap-felled stands where soil preparation was applied in the openings. If the ANOVAs indicated a difference among the catches, a Tukey's post-hoc test was performed to identify the difference(s).

The possible effects of logging and soil preparation on carabid assemblages were also studied by calculating Morisita's percentage similarity indices (e.g. Krebs 1999) for the yearly total catches of control stands, and gap-felled stands with and without preparation, i.e. for the data presented in Table 1. We also applied ordination methods (e.g. Jongman et al. 1995) in order to study the possible effects of the amounts of logging residue, drifted humus and exposed mineral soil, and wood-ant abundance. In the multivariate analyses, the groups of four traps were used as samples (six samples per stand). The above analyses were done using SYS-
TAT 8.0 (Anon. 1998a), NTSYSpc (Anon. 1998b) and CANOCO 4.0 (ter Braak and Šmilauer 1998) software.

\section{Results}

A total of 9722 carabid individuals, representing 27 species, was caught during 1995-1998 (Table 1). Carabids were first divided into three ecological groups according to their abundance patterns in mature and logged stands. The classification was done according to Lindroth (1985, 1986), Niemelä et al. (1993a), Kinnunen (1999) and Koivula (2002b): 1) forest species (species that are most abundant in closed phases of forest), 2) forest-habitat generalists (species that occur in various types of forested habitats, both mature forest and clear-cuts) and 3) open-habitat species (species that occur in open habitats, here clear-cuts). The forest-species group (5342 individuals, 8 species) was dominated by Calathus micropterus, which alone made up $84.1 \%$ of the catch. Forest generalist group (4325 individuals, 11 species) was dominated by Pterostichus oblongopunctatus, which made up $53.9 \%$ of the catch. Not surprisingly, these two species also dominated the total catch, making up together $70.2 \%$ of it. The catch of openhabitat species (55 individuals, 8 species) was dominated by Carabus cancellatus (38.2\% of the catch).

In 1995 (before logging), no open-habitat carabids were caught, but small numbers of these species were caught after logging: two individuals in 1996 (the first summer after logging), 28 (7 species) in 1997, and 25 (5 species) in 1998 (Table 1). In 1997, three individuals of open-habitat species were caught in the Kuorevesi control stand. This stand, however, is a small ( $<2 \mathrm{ha})$ mature-forest "island" on a hill, being surrounded by clear-cuts and young sapling stands. Therefore, it is more open than the other control stands. The first pioneers of open-habitat species thus arrived in the stands with openings within months after logging, but a pronounced increase took place one year after logging. Interestingly, the cluster dendrogram, based on Morisita's similarity indices (Fig. 2), suggests that the catches in stands with unprepared openings had changed most after logging. However, the overall similarities were relatively high. Among the catches from the stands with prepared openings and control stands, the similarity was over $85 \%$, and also the catches from the stands with unprepared openings had a 70\% similarity compared with the other treatments.

The yearly carabid catches peaked, in general, in 1997 (Table 2, Fig. 3). Moreover, the pooled forest-species catches were slightly higher in the unprepared openings than in the prepared ones (Gap f., logged vs Gap f. + prep., logged in Fig. 3), but the catches from different treatments did not differ statistically significantly from each other (Table 2). For Calathus mi- 
Table 1. The total catches of carabids in the study. Contr $=$ control stands, Unprep $=$ gap-felled stands without soil preparation, Prep $=$ gap-felled stands with soil preparation. Forest species in bold. The others represent open-habitat or habitat generalist species.

\begin{tabular}{|c|c|c|c|c|c|c|c|c|c|c|c|c|c|}
\hline \multirow[t]{2}{*}{ Species } & \multicolumn{3}{|l|}{1995} & \multicolumn{3}{|l|}{1996} & \multicolumn{3}{|l|}{1997} & \multicolumn{3}{|l|}{1998} & \multirow[b]{2}{*}{ Tota } \\
\hline & Contr & Unprep & Prep & Contr & Unprep & Prep & Contr & Unprep & Prep & Contr & Unprep & Prep & \\
\hline Calathus micropterus (Duftschmid) & 182 & 199 & 439 & 81 & 50 & 174 & 531 & 603 & 779 & 562 & 447 & 444 & 4491 \\
\hline Pterostichus oblongopunctatus (Fabricius) & 259 & 59 & 144 & 77 & 69 & 114 & 209 & 300 & 387 & 228 & 157 & 329 & 2332 \\
\hline Agonum fuliginosum (Panzer) & 2 & 69 & 1 & 5 & 76 & 0 & 90 & 794 & 10 & 4 & 304 & 6 & 1361 \\
\hline Carabus glabratus Paykull & 34 & 15 & 24 & 21 & 15 & 14 & 51 & 58 & 39 & 23 & 14 & 34 & 342 \\
\hline Pterostichus niger (Schaller) & 17 & 0 & 29 & 7 & 2 & 10 & 27 & 12 & 42 & 16 & 1 & 76 & 239 \\
\hline Carabus hortensis Linnaeus & 37 & 4 & 23 & 22 & 1 & 24 & 57 & 7 & 16 & 17 & 0 & 7 & 215 \\
\hline Patrobus assimilis Chaudoir & 0 & 17 & 1 & 4 & 29 & 4 & 7 & 55 & 3 & 2 & 62 & 7 & 191 \\
\hline Trechus secalis (Paykull) & 0 & 4 & 0 & 1 & 22 & 11 & 8 & 17 & 5 & 5 & 22 & 15 & 110 \\
\hline Amara brunnea (Gyllenhal) & 2 & 2 & 15 & 2 & 2 & 11 & 9 & 5 & 16 & 7 & 4 & 11 & 86 \\
\hline Notiophilus biguttatus (Fabricius) & 6 & 4 & 5 & 4 & 2 & 13 & 17 & 4 & 14 & 7 & 6 & 3 & 85 \\
\hline Harpalus quadripunctatus Dejean & 0 & 1 & 1 & 0 & 1 & 1 & 6 & 9 & 9 & 1 & 9 & 4 & 42 \\
\hline Agonum mannerheimii (Dejean) & 0 & 0 & 0 & 4 & 2 & 0 & 6 & 6 & 0 & 0 & 11 & 0 & 29 \\
\hline Pterostichus strenuus (Panzer) & 0 & 0 & 0 & 1 & 0 & 0 & 1 & 8 & 1 & 0 & 10 & 0 & 21 \\
\hline Carabus cancellatus Illiger & 0 & 0 & 0 & 0 & 0 & 2 & 1 & 6 & 4 & 0 & 5 & 3 & 21 \\
\hline Pterostichus diligens (Sturm) & 0 & 0 & 0 & 0 & 1 & 0 & 1 & 3 & 3 & 0 & 5 & 4 & 17 \\
\hline Amara lunicollis Schiødte & 0 & 0 & 0 & 0 & 0 & 0 & 0 & 1 & 1 & 0 & 3 & 5 & 10 \\
\hline Agonum sexpunctatum (Linnaeus) & 0 & 0 & 0 & 0 & 0 & 0 & 3 & 0 & 2 & 0 & 0 & 3 & 8 \\
\hline Notiophilus palustris (Duftschmid) & 0 & 0 & 0 & 0 & 0 & 0 & 0 & 4 & 0 & 0 & 2 & 2 & 8 \\
\hline Leistus terminatus (Hellwig in Panzer) & 0 & 2 & 0 & 1 & 0 & 1 & 0 & 0 & 1 & 1 & 1 & 1 & 8 \\
\hline Bembidion lampros (Herbst) & 0 & 0 & 0 & 0 & 0 & 0 & 0 & 0 & 2 & 0 & 0 & 0 & 2 \\
\hline Notiophilus aquaticus (Linnaeus) & 0 & 0 & 0 & 0 & 0 & 0 & 0 & 2 & 0 & 0 & 0 & 0 & 2 \\
\hline Dromius agilis (Fabricius) & 0 & 0 & 0 & 0 & 0 & 0 & 1 & 0 & 1 & 0 & 0 & 0 & 2 \\
\hline Trechus rubens (Fabricius) & 0 & 1 & 0 & 0 & 0 & 0 & 0 & 0 & 0 & 0 & 0 & 0 & 1 \\
\hline Trechus rivularis (Gyllenhal) & 0 & 0 & 0 & 0 & 0 & 0 & 0 & 0 & 0 & 0 & 0 & 1 & 1 \\
\hline Total & 547 & 378 & 693 & 240 & 275 & 387 & 1047 & 1898 & 1342 & 885 & 1065 & 965 & 9722 \\
\hline
\end{tabular}




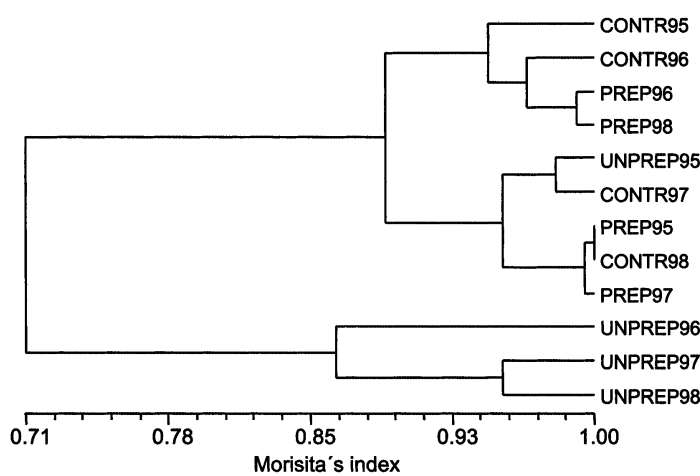

Fig. 2. The cluster tree for the data presented in Table 1, i.e the yearly total catches for the control stands (CONTR95CONTR98), stands with openings but without soil preparation (UNPREP95-UNPREP98), and stands with openings with preparation (PREP95-PREP98).

cropterus alone, catches in the control stands were marginally higher than those in the openings with soil preparation (post-hoc test: $\mathrm{p}=0.078$ ). The catches of another forest species, Carabus glabratus, the pooled catches of habitat generalists and the catches of a generalist, Pterostichus oblongopunctatus, also indicated no treatment effects (Table 2).

In the CCA, the four environmental variables (coverage of mineral soil, drifted humus, coverage of logging residue, and catches of red wood ants) together ex- plained $21 \%$ of the variation in the carabid dataset (Figs. 4 and 5). The total inertia was 2.372, and the two first axes together explained $7.5 \%$ of the variation in the species data and $81 \%$ of the species-environment relationship. The most important variable, the number of red wood ants, explained alone 11\% (199 Monte-Carlo permutations; $\mathrm{F}=10.92, \mathrm{p}=0.005)$, the amount of aggregated humus explained $4 \%$ more $(\mathrm{F}=3.63, \mathrm{p}=$ $0.005)$, and the percentage covers of exposed mineral soil and logging residue explained $3 \%$ each $(\mathrm{F}=3.10$, $\mathrm{p}=0.005$ and $\mathrm{F}=2.88, \mathrm{p}=0.020$, respectively). The variance inflation factor values for the environmental variables were relatively small (between 1.11 and 2.37), indicating that these variables did not correlate strongly with each other.

In the sampling site specific CCA scatter plot of the carabid data, the site scores of 1995 and 1996 aggregated more or less around the origin (Fig. 4). The yearly variation was seemingly in the up-right direction, since the scores of the control sites in 1997 and 1998 were in that direction. Although the result is not very clear, there was a weak indication of a treatment effect, since the scores of the sites in the openings (both prepared and unprepared) were to the left of the control-site scores. The species and environmental-variable scores of the CCA explain these patterns well (Fig. 5). The most numerous open-habitat species (Agonum sexpunctatum and Amara lunicollis) were located in the upper part of the plot. Moreover, the optima of logging residue and exposed mineral soil appeared above the

Table 2. The ANOVA results for (from top to bottom) the pooled catches of forest and generalist species, and for three species (Calathus micropterus, Carabus glabratus and Pterostichus oblongopunctatus). a = variation among the years 1996-1998, AREA = the three study areas, TREAT = six treatments: "logged" and "unlogged" control sites, unlogged and logged sites of the gap-felled stands but without soil preparation, and unlogged and logged + prepared sites of the gap-felled stands with soil preparation. The post-hoc test results indicate following. In the a rows, yearly differences are shown. In the AREA rows, e.g. $(2>3)=1$ indicates that the catches in Orivesi (area 2) were higher than in Kuorevesi (area 3), but the catches of Längelmäki (area 1) did not differ significantly from those of the other two areas. In one TREAT (AREA) row, [Contr $>\mathrm{O}+\mathrm{P}]$ indicates that the catches in the control stands were slightly higher $(\mathrm{p}<0.08)$ than those in the openings with preparation $(\mathrm{O}+\mathrm{P})$, while the other treatments did not differ significantly from each other or these two.

\begin{tabular}{|c|c|c|c|c|c|c|c|}
\hline Group & Source & SS & DF & MS & $\mathrm{F}$ & $\mathrm{p}$ & Post-hoc test \\
\hline \multirow[t]{4}{*}{ Forest spp. } & $\mathrm{a}$ & 196.03 & 2 & 98.02 & 10.50 & $<0.001$ & \multirow{4}{*}{$\begin{array}{l}1997>(1996=1998) \\
(2>3)=1\end{array}$} \\
\hline & $a \times$ AREA & 116.72 & 4 & 29.18 & 3.13 & 0.020 & \\
\hline & $\mathrm{a} \times$ TREAT(AREA) & 361.65 & 30 & 12.06 & 1.29 & 0.189 & \\
\hline & Error & 672.33 & 72 & 9.34 & & & \\
\hline \multirow[t]{4}{*}{ Generalists } & $\mathrm{a}$ & 730.12 & 2 & 365.06 & 5.20 & 0.008 & \multirow[t]{4}{*}{$1997>(1996=1998)$} \\
\hline & $\mathrm{a} \times \mathrm{AREA}$ & 258.63 & 4 & 64.66 & 0.92 & 0.457 & \\
\hline & $\mathrm{a} \times$ TREAT(AREA) & 2186.13 & 30 & 72.87 & 1.04 & 0.436 & \\
\hline & Error & 5058.26 & 72 & 70.25 & & & \\
\hline \multirow[t]{4}{*}{ C. micropterus } & $\mathrm{a}$ & 221.01 & 2 & 110.50 & 18.08 & $<0.001$ & \multirow{4}{*}{$\begin{array}{l}(1997=1998)>1996 \\
1>(2=3) \\
{[\text { Contr }>\mathrm{O}+\mathrm{P}]}\end{array}$} \\
\hline & $\mathrm{a} \times$ AREA & 113.27 & 4 & 28.32 & 4.63 & 0.002 & \\
\hline & $\mathrm{a} \times$ TREAT(AREA) & 334.28 & 30 & 11.14 & 1.82 & 0.020 & \\
\hline & Error & 439.96 & 72 & 6.11 & & & \\
\hline \multirow[t]{4}{*}{ C. glabratus } & $\mathrm{a}$ & 23.99 & 2 & 12.00 & 8.19 & 0.001 & \multirow[t]{4}{*}{$1997>(1996=1998)$} \\
\hline & $\mathrm{a} \times$ AREA & 16.68 & 4 & 4.17 & 2.85 & 0.030 & \\
\hline & $\mathrm{a} \times$ TREAT(AREA) & 63.460 & 30 & 2.12 & 1.45 & 0.104 & \\
\hline & Error & 105.43 & 72 & 1.46 & & & \\
\hline \multirow{4}{*}{ P. oblongop. } & $\mathrm{a}$ & 223.26 & 2 & 111.63 & 18.44 & $<0.001$ & \multirow{4}{*}{$\begin{array}{l}1997>(1996=1998) \\
3>(1=2)\end{array}$} \\
\hline & $\mathrm{a} \times$ AREA & 175.02 & 4 & 43.75 & 7.23 & $<0.001$ & \\
\hline & $\mathrm{a} \times \mathrm{TREAT}(\mathrm{AREA})$ & 267.60 & 30 & 8.92 & 1.47 & 0.092 & \\
\hline & Error & 436.00 & 72 & 6.06 & & & \\
\hline
\end{tabular}



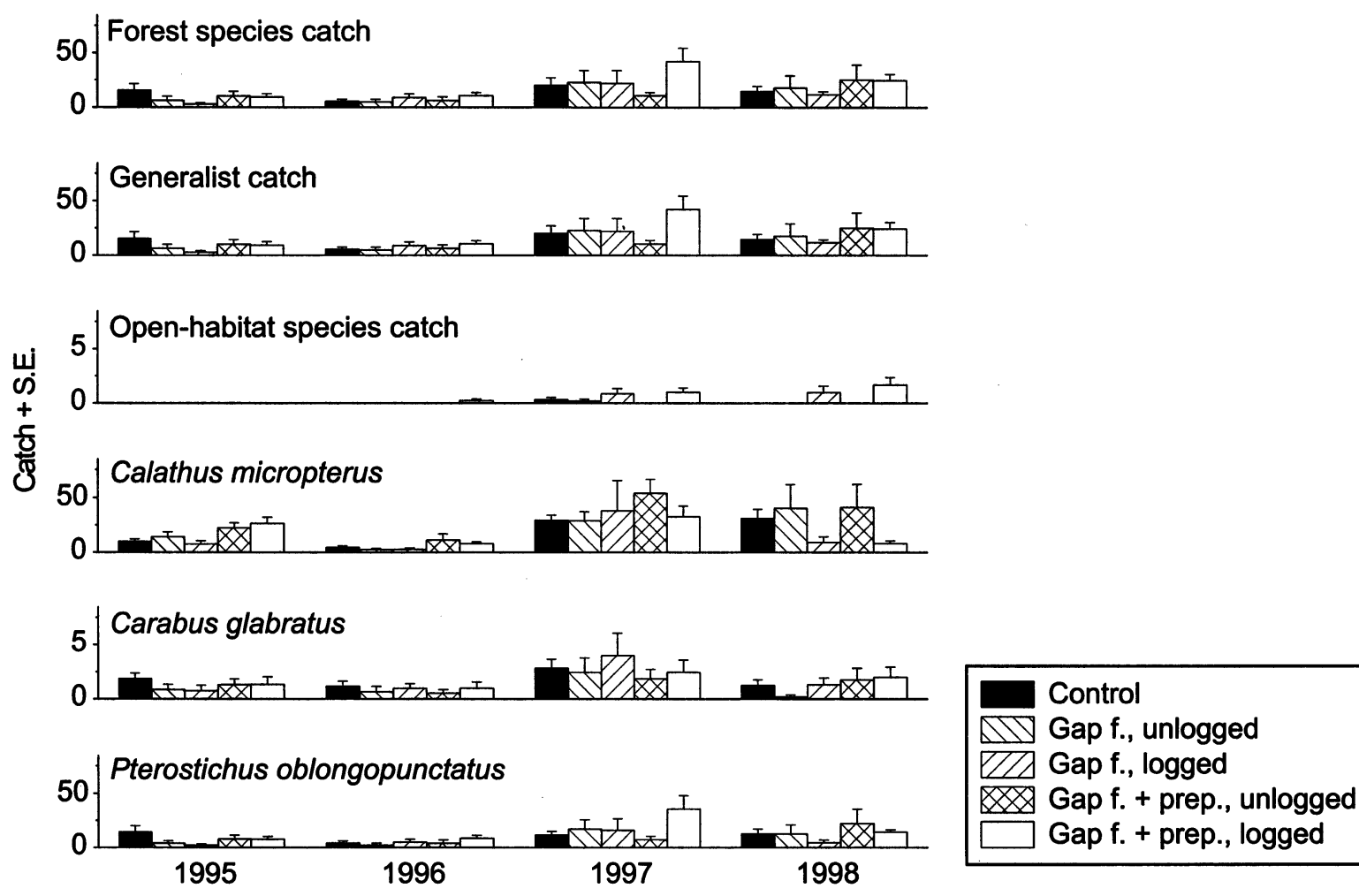

Fig. 3. The catches of the three species-ecological groups and three most abundant carabid species in 1995-1998. Control $=$ the catches of the control stands. Gap f., unlogged $=$ the catches of the unlogged sites within gap-felled stands. Gap f., logged $=$ the catches of the logged openings within gap-felled stands. Gap f. + prep., unlogged = the catches of the unlogged sites within gap-felled stands with prepared openings. Gap f. + prep., logged = the catches of the logged and prepared openings within gap-felled stands.

origin in the ordination plot. Forest specialists, on the contrary, were located in the lower left-hand side of the plot (Agonum mannerheimii, Carabus hortensis and $C y$ chrus caraboides). Along the horizontal axis, on the other hand, there was probably a moisture or "luxuriousness" gradient, since moisture-loving species (Agonum fuliginosum and Agonum mannerheimii) were on the left, while e.g. Notiophilus biguttatus, a species of well-lit, dry forest sites (Lindroth 1985), was on the right side of the species scatter. Additionally, this was the direction of the red wood ants, which are most numerous in relatively dry forest conditions (Punttila 1996).

\section{Discussion}

The most important results of this study can be summarised as follows. 1) The first individuals of openhabitat species colonised the small openings within months, but the increase was more pronounced one year after logging. 2) Catches of generalist species in the different treatments did not differ significantly from each other. 3) A forest species, Calathus micropterus, was slightly scarcer in the openings subjected to soil preparation than in the unlogged control sites. 4) The CCA and similarity-index results indicated that logging affected the species assemblages, but that soil prepara-

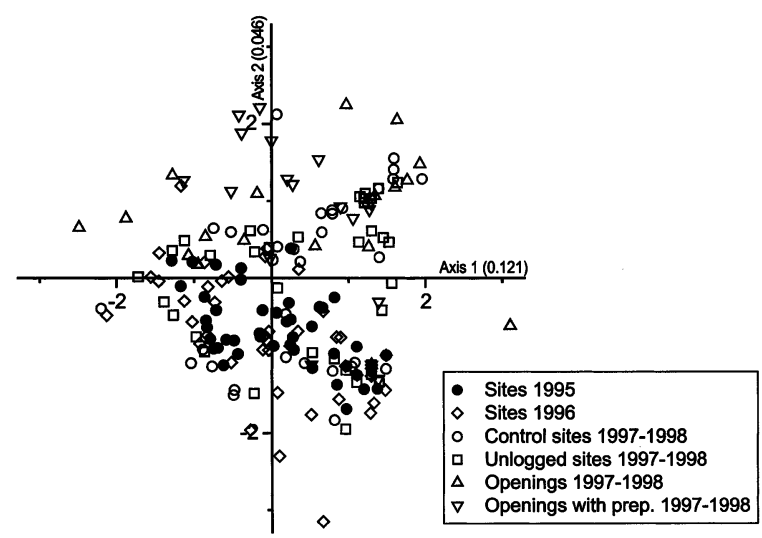

Fig. 4. The CCA sample scores for the study sites (groups of four traps) 1995-1998. To simplify the figure, the site symbols of 1995 are similar, as are the site symbols of 1996. The scores of 1997-1998 are treatment-specific but the years are not separated. The eigenvalues of the first two axes (Axis 1 and 2) are shown. 


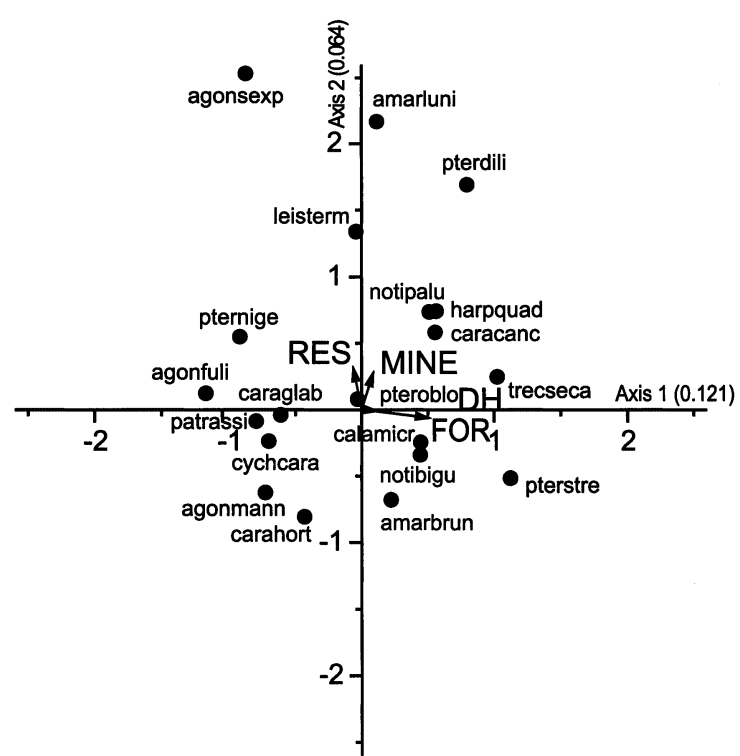

Fig. 5. The CCA species scores and the four environmental variables. $\mathrm{RES}=$ the percentage cover of logging residue, $\mathrm{MINE}=$ the percentage cover of exposed mineral soil, $\mathrm{DH}=$ the percentage cover of drifted humus and FOR $=$ the abundance of red wood ants (Formica) in the catches. The eigenvalues of the first two axes (Axis 1 and 2) are shown.

tion per se had no clear effects. However, the amounts of logging residue, exposed mineral soil, drifted humus and the abundance of red wood ants all explained variation in the carabid assemblages to a significant degree.

\section{Carabids in the managed forest landscape}

The result that carabid assemblages are affected by logging supports earlier studies (e.g. Lenski 1982, Niemelä et al. 1993a, b, Spence et al. 1996, Abildsnes and Tømmerås 2000, Koivula 2001, 2002a, b). However, these studies were carried out by trapping beetles in relatively large clear-cuts, while in the present study the clear-cuts were very small, being surrounded by mature forest. We can, therefore, conclude that open-habitat carabids are very efficient in colonizing recent, very small clear-cuts, since the first individuals arrived within months after logging. Their colonisation is enhanced by the presence of forest roads, which appear to be used as dispersal routes by these species (Koivula 2003). Also forest-habitat generalists were more abundant in the openings than in the unlogged trapping sites. We suggest that these species (e.g. Pterostichus niger, P. oblongopunctatus) do not necessarily have to arrive from nearby suitable habitats (although some individuals may, of course, do so) but, rather, increase locally in abundance, simultaneously with increasing openness - an analogy for the seed banks of several plant species.
The effects of soil preparation on carabids

Catches of Calathus micropterus were lower in the openings than in the unlogged study sites, which corroborates the results of Abildsnes and Tømmerås (2000) and Koivula (2002a, b). Also, catches were lowest in prepared openings, indicating that soil scarification had a negative effect on the population sizes of this species, and possibly also of other flightless forest-floor dwellers, e.g. spiders. However, our results regarding the similarities among the treatments indicated that actually the most pronounced changes happened in the unprepared openings. This contrasts with the views of Szyszko (1990) and Desender et al. (1999), who showed that there is a positive correlation between strength of habitat alteration and faunal change. The size of a clear-cut probably has an effect on the results, since Koivula (2002a) showed that, during the first years after clear-cutting, the carabid assemblages had changed much more in 2-ha clearcuts than in gap-felled stands, where only half of the area was patchily clear-cut. Also, the time period in our study was short compared with the other studies: the increased microsite spectrum in the prepared openings may ameliorate the immediate effects of logging.

It is possible that scarification increases the number of microsites with exposed mineral soil and, thus, creates suitable habitats for some species, as carabids respond to small-scale environmental variation (Niemelä et al. 1992). Mossakowski et al. (1990) observed that top-soil alteration, caused by military tanks, changed the abundance pattern of heath carabid assemblages, and hypothesized that it may be a result of increased habitat complexity. Likewise, we observed that open-habitat carabids were more abundant in the catches from openings than from unlogged trapping sites, while the other two species groups showed no clear declines or increases in their catches. Also M. Pihlaja (unpubl.) observed differences between carabid catches in sites with exposed soil as compared to unaltered forest floor in the clear-cuts.

\section{Conclusions}

According to our results, soil preparation has no strong effects on forest-floor carabids, but populations of some species may either suffer (e.g. Calathus micropterus) or benefit from the microhabitat alteration caused by soil preparation. Species that benefit might be those that are associated with open sites with plenty of exposed mineral soil. Soil preparation also creates microsites with drifted humus. These sites, together with logging residue left behind in the clear-cuts, may increase microhabitat richness of 
openings, thus affecting carabid assemblages. However, Jalonen and Vanha-Majamaa (2001) showed in the same study sites as the present study - that soil preparation causes drastic changes in the understory vegetation. Thus, changes may appear in taxa that directly use soil as a nutrient storage, shelter and habitat, such as plant and soil fungal communities.

Compared to relatively small alterations caused by soil scarification that was studied in this paper, even smaller faunal changes would be expected if the humus layer is removed only patchily, mimicking uprooting of windthrown trees to help saplings to establish easier. This method is today commonly used in Finnish forest management. Soil preparation methods lighter than ploughing seem nevertheless to help assemblages of ground dwellers to maintain their populations at the logged stands.

Acknowledgements - We thank Janne Heliölä, Minna Kuusipalo and Marjo Pihlaja for assistance in the field. Kari Vepsäläinen helped with the NTSYSpc analysis. MK was financed by the Academy of Finland, Finnish Cultural Foundation, Finnish Ministry of Forestry and Agriculture, and Metsämiesten Säätiö foundation

\section{References}

Abildsnes, J. and Tømmerås, B. ^. 2000. Impacts of experimental habitat fragmentation on ground beetles (Coleoptera, Carabidae) in a boreal spruce forest. Ann. Zool. Fenn. 37: 201-212.

Ahti, T., Hämet-Ahti, L. and Jalas, J. 1968. Vegetation zones and their sections in northwestern Europe. - Ann. Bot. Fenn. 5: 169-211.

Andrén, H. 1997. Habitat fragmentation and changes in biodiversity. - Ecol. Bull. 46: 171-181.

Angelstam, P. 1997. Landscape analysis as a tool for the scientific management of biodiversity. - Ecol. Bull. 46: $140-170$.

Angelstam, P. and Pettersson, B. 1997. Principles of present Swedish forest biodiversity management. - Ecol. Bull. 46: $191-203$.

Anon. 1998a. SYSTAT 8.0 for Windows. - SPSS

Anon. 1998b. NTSYSpc vers. 2.02h. - Applied Biostatistics.

Cajander, A. K. 1949. Forest types and their significance. Acta For. Fenn. 56: 1-71.

Desender, K., Ervynck, A. and Tack, G. 1999. Beetle diversity and historical ecology of woodlands in Flanders. Belgian. J. Zool. 129: 139-155

Digweed, S. C. et al. 1995. Digging out the "digging-in-effect" of pitfall traps: influences of depletion and disturbance on catches of ground beetles (Coleoptera: Carabidae). - Pedobiologia 39: 561-576.

Esseen, P.-A. et al. 1997. Boreal forests. - Ecol. Bull. 46: $16-47$.

Fries, C. et al. 1997. Silvicultural models to maintain and restore natural stand structures in Swedish boreal forests. - For. Ecol. Manage. 94: 89-103.

Haila, Y. et al. 1994. Forestry and the boreal fauna: matching management with natural forest dynamics. - Ann. Zool. Fenn. 31: 187-202.

Hallman, E. et al. 1996. Alue-ekologinen suunnittelu. Finnish Forest and Park Service, Vantaa, in Finnish.

Heikkinen, R. et al. 2000. Suojelualueverkon merkitys metsälajistolle: lehtojen putkilokasvit, metsien lahopuuko- vakuoriaiset, havu- ja sekametsien linnut. - Finnish Environment Center and Finnish Forest and Park Service, Helsinki, in Finnish with English summary.

Jalonen, J. and Vanha-Majamaa, I. 2001. Immediate effects of four different felling methods on mature boreal spruce forest understorey vegetation in southern Finland. - For. Ecol. Manage. 146: 25-34.

Jongman, R. H. G., ter Braak, C. J. F. and van Tongeren, O. F. R. (eds) 1995. Data analysis in community and landscape ecology, 2nd ed. - Cambridge Univ. Press.

Kinnunen, H. 1999. In search of spatial scale - carabid beetle communities in agricultural landscapes. - Ph.D. thesis, Univ. of Helsinki.

Koivula, M. 2001. Carabid beetles (Coleoptera, Carabidae) in boreal managed forests - meso-scale ecological patterns in relation to modern forestry. - Ph.D. thesis, Univ. of Helsinki.

Koivula, M. 2002a. Alternative harvesting methods and boreal carabid beetles (Coleoptera, Carabidae). - For. Ecol. Manage. 167: 103-121.

Koivula, M. 2002b. Carabid beetles (Coleoptera, Carabidae) in thinned uneven-aged and clear-cut spruce stands. Ann. Zool. Fenn. 39: 131-149.

Koivula, M. 2003. Forest roads - a landscape element affecting the spatial distribution of boreal carabid beetles. - In: Szyszko, J. et al. (eds), Ecology and conservation of carabid beetles. Proc. X European Carabidologists Meeting, Warsaw, in press.

Koivula, M. et al. 1999. Leaf litter and the small-scale distribution of carabid beetles (Coleoptera, Carabidae) in the boreal forest. - Ecography 22: 424-435.

Krebs, C. J. 1999. Ecological methodology, 2nd ed. - Addison-Wesley Educational Publ., Benjamin/Cummings.

Lenski, R. E. 1982. The impact of forest cutting on the diversity of ground beetles (Coleoptera: Carabidae) in the southern Appalachians. - Ecol. Entomol. 7: 385-390.

Lindroth, C. H. 1985. The Carabidae (Coleoptera) of Fennoscandia and Denmark. Vol. 15, part 1. - Fauna Entomologica Skandinavica, Leiden, Copenhagen.

Lindroth, C. H. 1986. The Carabidae (Coleoptera) of Fennoscandia and Denmark. Vol. 15, part 2. - Fauna Entomologica Skandinavica, Leiden, Copenhagen.

Mönkkönen, M. 1999. Managing Nordic boreal forest landscapes for biodiversity: ecological and economic perspectives. - Biodiv. Conserv. 8: 85-99.

Mossakowski, D., Främbs, H. and Baro, A. 1990. Carabid beetles as indicators of habitat destruction caused by military tanks. - In: Stork, N. E. (ed.), The role of ground beetles in ecological and environmental studies. Intercept, Andover, Hampshire, pp. 237-243.

Niemelä, J. 1997. Invertebrates and boreal forest management. - Conserv. Biol. 11: 601-610.

Niemelä, J. 1999. Management in relation to disturbance in the boreal forest. - For. Ecol. Manage. 115: 127-134.

Niemelä, J. et al. 1992. Small-scale heterogeneity in the spatial distribution of carabid beetles in the southern Finnish taiga. - J. Biogeogr. 19: 173-181.

Niemelä, J. et al. 1993a. Logging and boreal ground beetle assemblages on two continents: implications for conservation. - In: Gaston, K. J., New, T. R. and Samways, M. J. (eds), Perspectives in insect conservation. Intercept Publ., Andover, Hampshire, pp. 29-50

Niemelä, J., Langor, D. W. and Spence, J. R. 1993b. Effects of clear-cut harvesting on boreal ground beetle assemblages (Coleoptera: Carabidae) in western Canada. Conserv. Biol. 7: 551-561.

Punttila, P. 1996. Succession, forest fragmentation, and the distribution of wood ants. - Oikos 75: 291-298.

Rassi, P. et al. 2000. Suomen lajien uhanalaisuus 2000. Uhanalaisten lajien II seurantatyöryhmä. - Finnish Ministry of Environment, in Finnish. 
Savolainen, J. (ed.) 1997. Metsälaki perusteluineen. - Edita, Helsinki, in Finnish.

Sklodowski, J. 1999. Znaczenie wielkośki biogrupy pozostawionej na zrębie $\mathrm{w}$ ochronie gatunkowej na przykladzie rodziny biegaczowatych Col. Carabidae. - Katedra Ochrony Lasu I Ekologii SGGW, in Polish.

Spence, J. R. et al. 1996. Northern forestry and carabids: the case for concern about old-growth species. - Ann. Zool. Fenn. 33: 173-184.
Szyszko, J. 1990. Planning of prophylaxis in threatened pine forest biocenoses based on an analysis of the fauna of epigeic Carabidae. - Warsaw Agricult. Univ. Press, Warsaw.

ter Braak, C. J. F. and Smilauer, P. 1998. Canoco for Windows vers. 4.0. - Centre for Biometry, Wageningen.

Underwood, A. J. 1991. Beyond BACI: experimental designs for detecting human environmental impacts on temporal variations in natural populations. - Aust. J. Mar. Freshwater Res. 42: 569-587. 